\title{
Modern means of assessing the impact of emergencies on the environmental condition of the ground layer of atmosphere
}

\author{
Anastasiia Turevych ${ }^{1}$, Svitlana Madzhd ${ }^{1}$, Larysa Cherniak $^{1}$, Anatoliy Pavlyuk ${ }^{2}$, and Vincent Ojeh ${ }^{3}$ \\ ${ }^{1}$ National Aviation University, Kyiv, Ukraine \\ ${ }^{2}$ Nikolaev Institute of Inorganic Chemistry, Siberian Branch of Russian Academy of Sciences, Novosibirsk, Russia \\ ${ }^{3}$ Taraba State University, Jalingo, Nigeria
}

\begin{abstract}
The problem of emergencies will not leave humanity as long as it exists, and therefore it is necessary to at least create conditions under which it is possible to reduce the risks of injuries, diseases and deaths of people who are in the emergency zone. This can be achieved by raising awareness of the nature of the emergency, the hazardous substances that are released in connection with it. Theoretical analysis of various remote means of assessing the impact of emergencies of man-made areas on the ecological state of the atmospheric air of the surrounding areas. It has been found that the use of remote sensing equipment greatly simplifies the procedure of operational monitoring of the environment during emergencies, as well as contributes to the health of professionals. A comparison of different remote means of environmental monitoring of air quality was performed: In particular, stationary automatic stations, mobile automatic stations, probes, and unmanned aerial vehicles (UAVs) were compared. It is proposed to use UAVs as remote means of operational monitoring of air quality. The functional scheme of UAV system implementation for the needs of operative ecological monitoring is offered. The legal features of the use of unmanned aerial vehicles as remote means of monitoring air quality during emergencies are analyzed.
\end{abstract}

\section{Introduction}

With the growth of the technological and economic crisis, the absolute number of the new man-made emergencies and accidents at enterprises and infrastructure of settlements is growing. The introduction of new technologies and timely modernization can reduce the number of accidents, but the risk of their occurrence cannot be reduced to absolute zero.

The rational usage of nature involves not only ecologically balanced management of natural resources, but also the creation and maintenance of a safe environment for future generations. This is achieved through the implementation of the provisions of the concept of sustainable development not only in the objects of entrepreneurial activity, but also in the processes of control and management of environmental quality.

The deterioration of qualitative and quantitative characteristics of the surface layer of air leads to negative consequences [1] not only for the biosphere as a whole, but also to increase the impact on public health [2] and the increasing number of diseases and allergies. The reverse effects observed by scientists around the world related to the SARS-CoV-2 epidemic are also possible [3-5].

Nowadays the solving of the problems related to the state of the environment involves the usage of the latest technologies and developments, as well as the application of approaches to sustainable development and the functioning of environmental quality management systems.

This is especially important for the control of manmade objects and territories, as well as for the detection and elimination of emergencies and their consequences. Within the framework of this direction the state programs are formed, important researches are carried out [6-9].

The related research requires the use of modern scientific and technological progress, the creation and use of the latest information-measuring and softwarehardware complexes. The effectiveness of their use depends on the level of development, the use of hardware and software measurement tools and the ability to work effectively with the information obtained.

During emergencies at man-made sites, large volumes of mostly toxic substances are usually released into the air, but the low speed of response of specialists, as well as physical defects do not allow to quickly identify the location of harmful substances in the environment. As a result of lost time, the company, service organization or country incurs significant economic and social and labor losses for each unit of time.

The usage of remote multispectral and multisensory means will reduce the response time of specialists to a call in case of an emergency or threatening situation on the territory, as well as reduce the risk of injuries and diseases of specialists in performance of official duties. 
The aspects of this issue were considered by many well-known scientists. Thus, O.O. Popov, A.V. Iatsyshyn, V.O. Kovach, V.O. Artemchuk, T.M. Iatsyshyn, A.O. Zaporozhets, V.M. Isaenko, S.M. Majd, J. Burgués, S. Marco, A. Arfire, A. Marjovi, A. Martinoli, N. Castell, M. Kobernus, H.-Y. Liu, P. Schneider, W. Lahoz, A.J. Berre, J. Noll and others were engaged in solving problems of ecological safety of energy and public utilities, but the issue of developing new or improving existing means to improve the environmental safety of man-made areas during emergencies in case of nonradiation pollution of surface air remain relevant and important for many developed countries.

The study was conducted to analyze the existing means of monitoring air quality during emergencies in man-made areas and potentially dangerous objects to develop and implement a more effective means of operational monitoring of atmospheric air.

Within the framework of the aim it is planned to solve the following tasks:

- identify the features of the mechanisms of the ecological management system of the techno-ecosystem;

- to analyze pollutants that require special control in the emergency area;

- Investigate approaches to the mathematical description of the movement of pollutants in the ground layer of the atmosphere;

- propose the approach to optimize crisis monitoring and management of the ground layer of atmospheric air in areas of emergencies or potential emergencies.

\section{Materials and methods}

This study was mainly conducted on the basis of domestic and foreign publications on methods of management and monitoring of man-made objects and areas during planned activities and during emergencies, as well as on the basis of the authors of this study.

The following research methods were used: method of comparative analysis, modeling and evaluation of the impact of emergencies on the quality of the ground layer of atmospheric air.

\section{The research results}

\subsection{Ground layer of atmospheric air, features of definition}

Nowadays there is no clear definition of the term "ground layer of the atmosphere" in Ukrainian terminology, so State standard of technical conditions of Ukraine (DSTU) 3513-97 "Meteorology: Terms" [10] indicates the surface layer of the atmosphere as "The lower part of the boundary layer of the troposphere, which interacts most intensely with the underlying surface". In spite of, this formulation is not very accurate and does not indicate the boundaries of the layer of the atmosphere that is most affected by the underlying surface, i.e. the habitat of most living organisms, and in particular humans.
According to Directive 2008/50 / EC of the European Parliament and of the Council of 21 May 2008 about air quality and cleaner air for Europe [11], the optimal level of measurement of pollutants to be considered safe or unsafe for human health the height of $1.5 \mathrm{~m}$ above ground level is determined, in other words, the average statistical height of a person. At the same time, for the description, modeling and forecasting of pollutant levels in the surface layer of the atmosphere, the data obtained from a height of $1.5 \mathrm{~m}$ is not enough, so it is necessary to determine the highest point of the range of air quality parameters.

O.G. Shevchenko performed studies [12] of the influence of physical processes potentially caused by the influence of the earth's surface on the concentration of pollutants: sulfur dioxide and nitrogen dioxide, at an altitude of 10 to 500 meters above ground level. According to this study, at altitudes of $251-500 \mathrm{~m}$, pollutants that enter the atmosphere from high emission sources (enterprise flares) are significantly affected by meteorological phenomena and changes in the trajectory. At altitudes of $10 \mathrm{~m}$ to $250 \mathrm{~m}$, low and medium emission sources are the main influence.

However, at heights from the direct underlying surface (conditionally zero height) to $1.5 \mathrm{~m}$, there is also a significant and direct impact of the surface on atmospheric air: erosion of soils, evaporation of water, release of pollutants from leaks and exhaust pipes of some types of vehicles. Most of the substances released in this way after entering the atmosphere thus rise to a height of more than $1.5 \mathrm{~m}$ and are carried further.

Therefore, in accordance with the above, the authors consider that the ground layer of the atmosphere is the airspace at altitudes from $1.5 \mathrm{~m}$ to $500 \mathrm{~m}$ inclusive.

\subsection{Features of the impact of emergencies on technogenically loaded objects on the environment}

The peculiarities of the distribution of pollutants in the air were described in the 1970-s by M. Berland [13], who determined that the main factors influencing the spread of impurities in the atmosphere are wind and the distribution of air temperature with altitude.

Industrial emissions can come from sources of different heights: from industrial pipes (flares), from sources at ground level, and so on. If the temperature of the gas released from the source is higher than the ambient air, the former are characterized by a certain dynamism. According to the research of $\mathrm{M}$. Berland, and a group of scientists led by O.O. Popov [14] in the vicinity of the emission source creates a field of vertical velocities, attenuating with distance from the source, which sometimes extends over long distances and helps to raise the impurity up.

The process of transferring impurities to the upper atmosphere is called atmospheric stratification and can be defined as the category of stability of the atmosphere.

The state of the atmosphere can be equilibrium, stable and unstable. The degree of stability of the atmosphere determines the behavior of the air particle (elementary 
volume of air), removed from the original position, in the upper or lower layer of the atmosphere.

According to the laws of physics, a particle of warm air rises and a particle of cold air descends.

In the troposphere there is a decrease of temperature with increasing altitude, which has a direct impact on the "state of the atmosphere". The atmosphere in a particular place can be in several different states in their physical characteristics:

1) the state of equilibrium stratification - air particle moving in a certain direction, takes the temperature of the ambient air and its density becomes equal to the density of the surrounding particles, therefore, the cause of its rise or fall is leveled;

2) the state of stable stratification of the atmosphere if the vertical temperature gradient in the atmosphere is less than at equilibrium, the particle moving up will cool and will soon become colder than the surrounding air, and heavier than it. Therefore, it will fall and return to its original position;

3) the state of unstable stratification - if the vertical temperature gradient is more than equilibrium, the air particle, starting to move up or down, will continue its movement with increasing acceleration. The farther it goes from the initial position, the more its temperature deviates from the ambient temperature [13]. In this case, we talk about unstable stratification.

Another characteristic of the description of the state of the atmosphere is the so-called inversion, which is defined as an increase in temperature with altitude. Temperature inversion can occur both near the earth's surface (surface inversion) and at a certain height (altitude inversion). If the inversion occurs at a certain height above the ground, it is called elevated. Increased inversion can create dangerous conditions for the population living in white man-made areas, due to the fact that emissions cannot rise above a certain level - the "ceiling", the effect of which such an inversion creates.

Information on the fundamentals of the functioning of the atmosphere in its various parts is very important for determining the qualitative and quantitative indicators of air quality at any time, in particular during the operational monitoring of air quality in the emergency zone or during a technogenical accident. It is especially important for forecasting the consequences [14] and effective environmental safety management in areas of such situations. For example, it is also important for the effective assessment and management of the atmosphere that pollutants enter the atmosphere not only from certain stationary or mobile sources of emissions, but can be discharged from the surface of the earth, which has been man-made and anthropogenic, in particular in Ukraine. scientists [16] on the territory of Boryspil International Airport.

\subsection{Remote atmospheric research tools as the first and important link in the crisis monitoring system during emergencies}

Unfortunately, modern measuring instruments do not provide enough attention in the scientific community, and the instruments used in the national practice of Ukraine are often difficult to call modern. This primarily affects the accuracy of measurements and, consequently, the reliability of control over the quality of the environment. At the same time, when it comes to technical means and systems of air pollution control, the most effective, accurate, operational are optical, in particular, multispectral systems and multisensory systems, that allow express and at the same time high-precision control of air pollution in selected research ranges.

Multispectral research devices are imaging devices (image or set of images) in which data are recorded in certain wavelength ranges in the electromagnetic spectrum [17]. Wavelengths can be separated by optical filters or by sensors sensitive to specific lengths waves, including light having frequencies outside the visible range, such as infrared and ultraviolet [18]. Spectral visualization allows you to get additional information that cannot be seen by the human eye with limited receptors for the vision of blue, green, red. Such tools are usually part of geographic information systems that are built on the basis of satellites [19].

In contrast, multisensory devices are based on a number of different types of sensors, including optical, which allow to obtain a more informative and accurate conclusion about the quality of atmospheric air in a particular study area.

When the research is performed manually, using any research tools, there is an error of measurement caused by the human factor. Proven accurate remote sensing tools should be used to minimize human exposure during studies that require high accuracy and time.

Remote means of environmental quality research (Fig. 1) can be in the form of meteorological probes, remote manned or automated robots, unmanned aerial vehicles (UAVs) with installed video, infrared cameras and almost any sensors.

The most common remote means of air quality control are state (municipal) systems built on the basis of a set of stationary automatic stations (Fig. 1 a). Such systems have proven to be the main means of systematic air quality monitoring of large cities, suburbs, industrial regions, protected areas, etc. They allow to conduct fundamental research [20-22] of the patterns of movement and deposition of various pollutants [10], as they have a very high accuracy of equipment, the ability to work around the clock. The main disadvantages of these systems are the high cost of placement and operation, stationary, the overwhelming inability to quickly disassemble and move the observation station to another location (extremely low mobility).

One of the rather new methods of studying the historical levels of air pollution is the method of dendrochemistry [23], which was considered by a group of Italian scientists led by Edoardo Alterio, who proved the convenience and accuracy of this method of historical analysis of air quality. Without regard to, this method is not suitable for determining the actual levels of air pollution at the time of measurement.

The use of small cheap analogues of stationary atmospheric air monitoring stations - portable stations - is also quite widespread. Based on a system of municipal 
(large) and portable cheap (small) stations, there are online services (Fig.2.) that disseminate information about the relative air quality at a certain point. These relative readings are called the "Air Quality Index", which is calculated [49-50] on the basis of basic measurable indicators - dust particles, carbon oxides, nitrogen and sulfur.
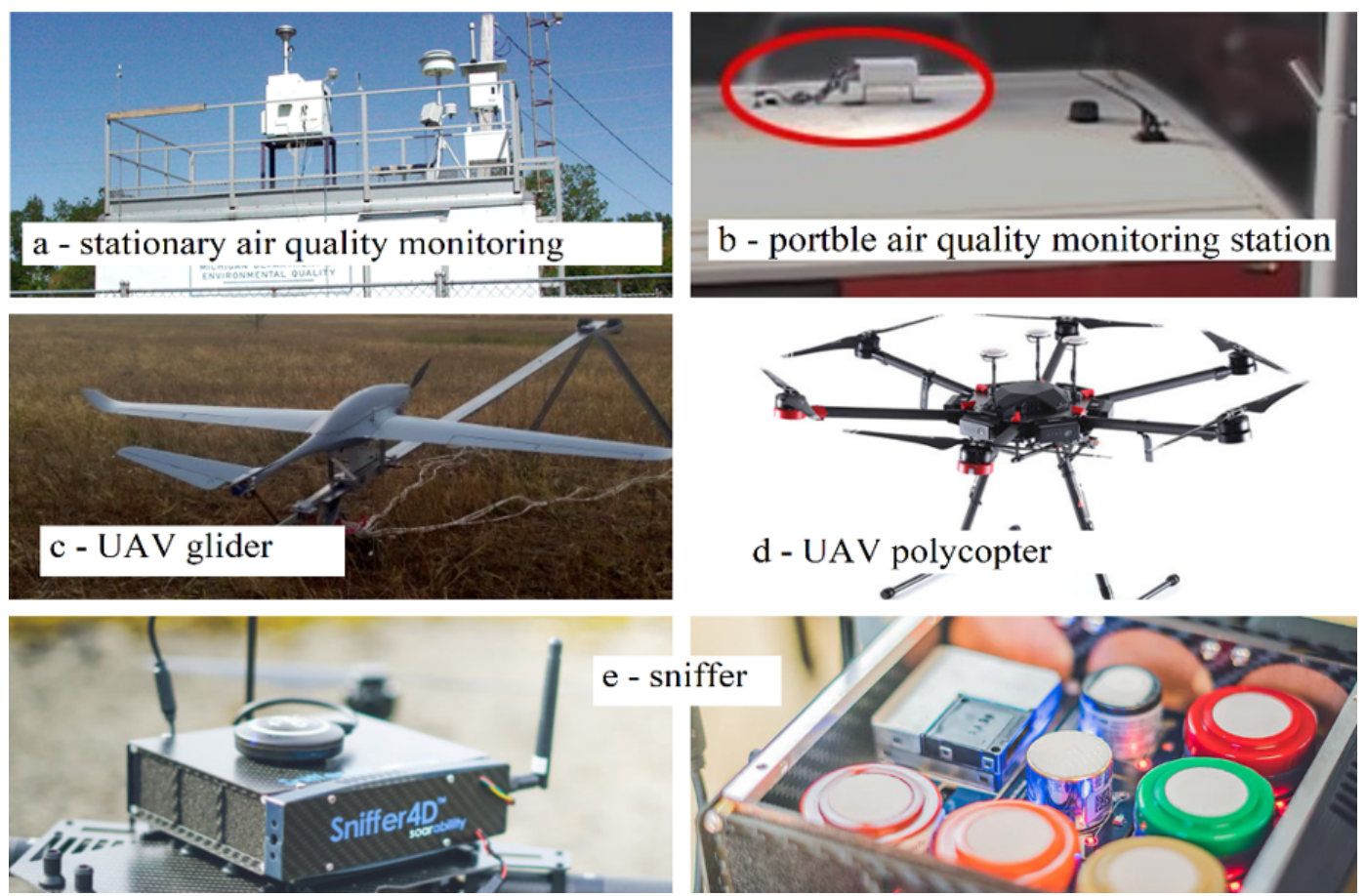

d - UAV polycopter

$1 p$

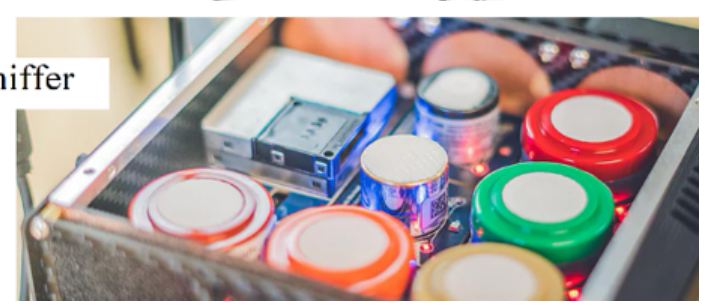

Fig. 1. Remote Environmental Monitoring tools [39,45-48].

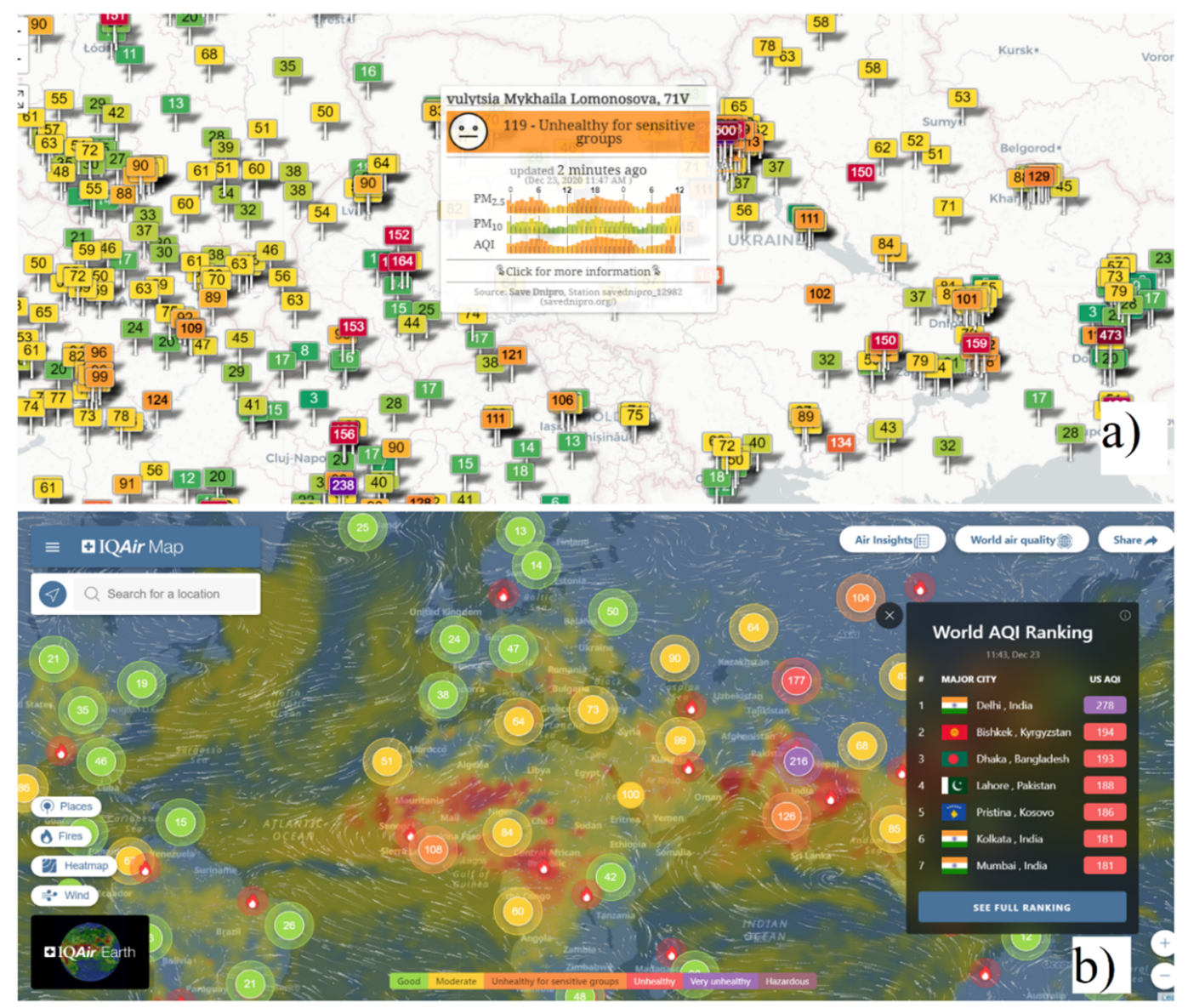

Fig. 2. Examples of online services for information about air quality and air pollution: a) aqien.org and b) iqair.com. 

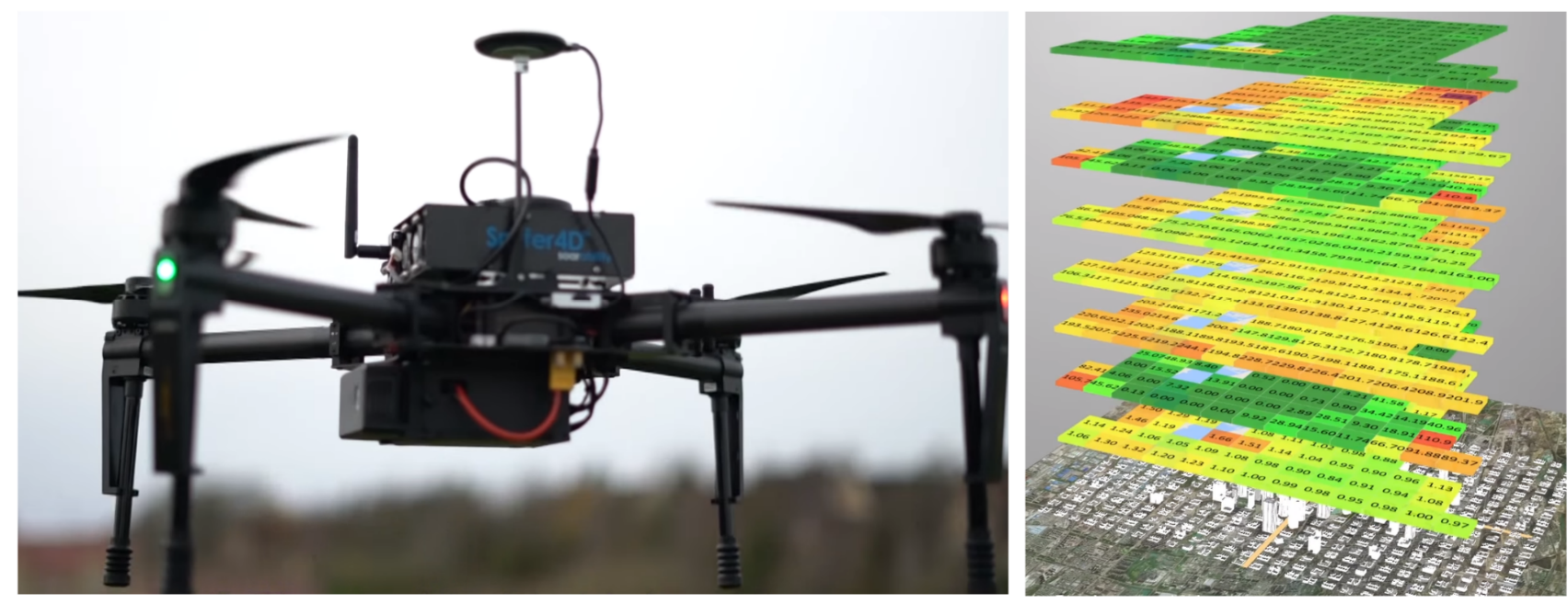

Fig. 3. Effective use of UAVs for manual air quality monitoring [39].

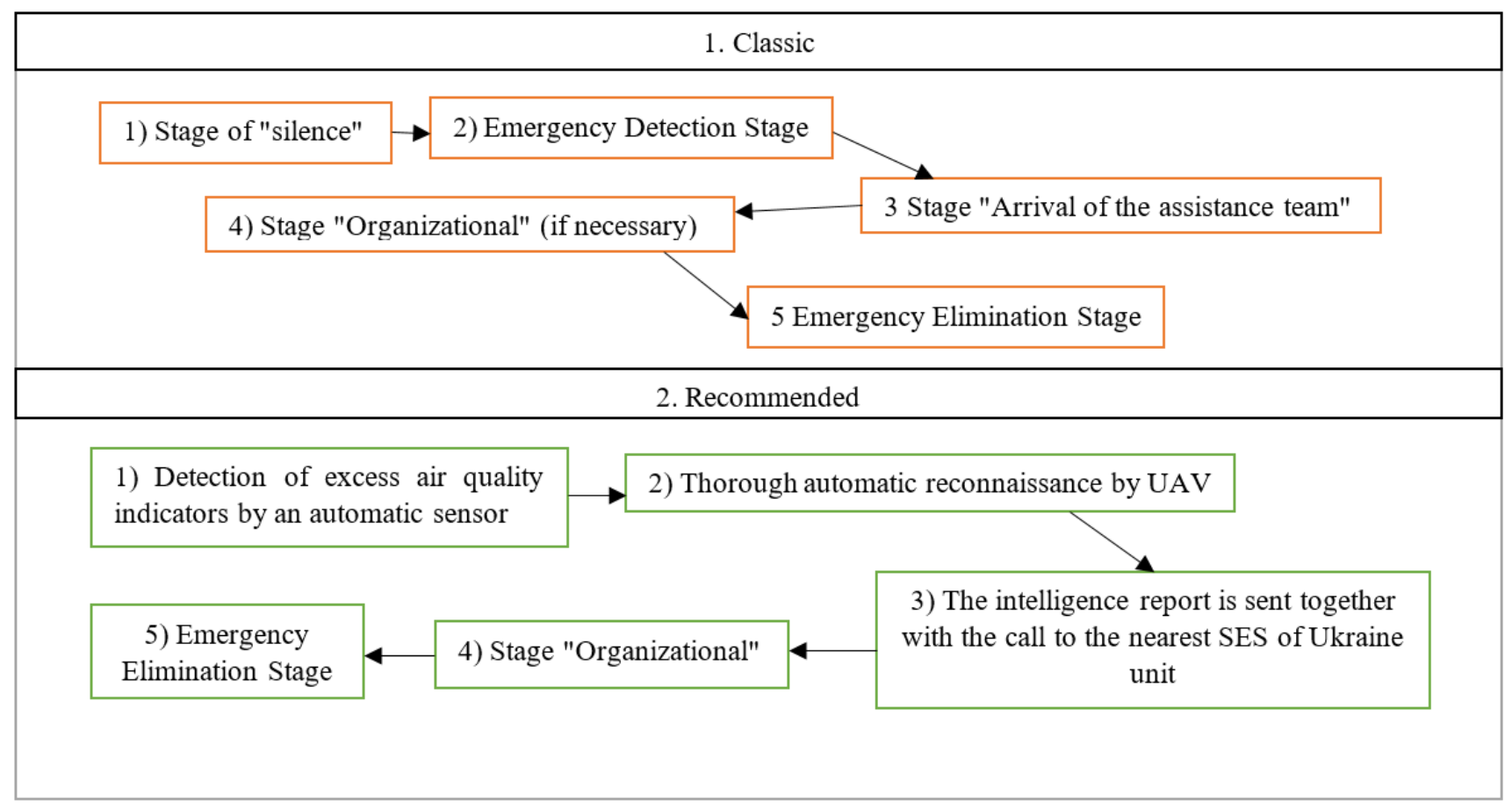

Fig. 4. Simplified response scheme of the rescue service (SES of Ukraine) to emergencies.

In the world of rapid development, the use of various sensors located in the systems of public, leased and private transport to study the parameters of air quality (Fig.1 b). In particular, A. Arfire, A. Marjovi, A. Martinoli, N. Castell, M. Kobernus, H.-Y. Liu, P. Schneider, W. Lahoz, A.J. Berre, J. Noll, L. Kang, S. Poslad, W. Wang, X. Li, Y. Zhang, C. Wang, G. Lancia, F. Rinaldi, P. Serafini, L. Liu, J. Duan, Z. Xiao, H.P. Raju, P. Partheeban, R.R. Hemamalini at al. have their scientific achievements in this field [24-30]. It is based on the use of the concept of the Internet of Things, to create and group sensor systems that are in some way placed on vehicles and combine them with computer centers that transmit information about the state of the air in the city to the Internet. Such systems are currently used successfully in cities and regions such as Chennai (India) [29], Lausanne and Zurich (Switzerland) [24] and Rome
(Italy) [27]. Similar systems are also being tested in several regions of China [26, 28]. Such means of studying the quality of atmospheric air can be considered remote, due to the lack of a direct person-performer of measurements, the latter are performed automatically. In some systems, even the sensors are calibrated by a measuring device without assistance in an autonomous automatic mode [25].

Radioacoustic sounding of the atmosphere as a means and method of remote environmental monitoring, presented in the works of E.G. Tolstih [31]. This method is based on the passive radar spot of scattered electromagnetic oscillations and allows you to remotely measure such characteristics of atmospheric air as humidity, temperature, pressure and other physical indicators of air quality. Notwithstanding, radioacoustic sounding does not allow to determine the qualitative and 
quantitative values of aerosol and dust air pollution, as well as its chemical components in relative and / or absolute form - gases, water vapor, etc.

The studies based on the introduction of unmanned aerial vehicles into active scientific, industrial and public use have become very popular and widespread. At present contemporary UAVs are used: in biology to explore new, previously inaccessible corners of the planet and studied their flora and fauna [32]; in emergency services for the introduction of effective means of searching for victims of disasters and emergencies, in particular in the rubble of buildings [3334]; in the fields of marketing and logistics for the development of services of delivery and dissemination of unimpeded provision of the population of remote places with the necessary means of subsistence [35], in the military sphere for search and general intelligence [36] and in the socio-cultural sphere for entertainment and leisure filming, video-blogging, photo and video shooting of sports competitions and concerts [37]. In the field of environmental safety, A.O. Zaporozhets, J.Burgués, S. Marco, R. Noori and D.P. Dahnil are using UAV-based technologies.

The use of UAV-based monitoring systems has found its use not only to study air quality, but also to perform research on the reliability of power grids and other energy and infrastructure facilities. [51-53].

Researcher of the Institute of Technical Thermophysics of the National Academy of Sciences of Ukraine A.O. Zaporzhets carried out a research project to create an air quality monitoring system based on the use of a set of methods for obtaining information on the state of the atmosphere: UAVs and the existing system of planned monitoring based on stationary and mobile air quality monitoring posts. In his work, he focused on planned, i.e. continuous monitoring of industrial facilities and proposes to study the air for the content of $\mathrm{O} 2, \mathrm{CO}$, $\mathrm{CO} 2, \mathrm{NO}, \mathrm{NO} 2, \mathrm{SO} 2, \mathrm{H} 2 \mathrm{~S}$ at an altitude of $50 \mathrm{~m}$ to $1 \mathrm{~km}$ using UAV glider (fig. 1 c) and helicopter types [38].

Spanish scientists J. Burgués \& S. Marco have developed an effective device (Fig. 1 e) for air sampling during monitoring of polycopter type UAVs - sniffer (sensor unit) of atmospheric quality [39], performing a significant analysis of research conducted today on the location and execution of sniffers for use in unmanned aerial vehicles during continuous scheduled monitoring of air quality in cities (Fig. 3.). The problem with their sensor unit is: too dense placement of sensors, which can affect the work of each other and interfere with the uniform blowing of all sensors, as well as the narrow specialization of the sniffer and the impossibility of its use on various unmanned aerial vehicles, as Burgués, J., $\&$ Marco, S specialized in their invention for use with only three models of helicopters brand DJI M100/210/600, as well as on cars.

Researchers R. Noori \& D.P. Dahnil from the University of Malaysia Kebangsaan proposed the use of a six-beam polycopter (Fig. $1 \mathrm{~d}$ ) for use in studies of environmental quality indicators [40]. In their work, they tried to test the efficiency of the polycopter to determine the effectiveness of various equipment for measuring the concentration of four indicators of air quality: smoke, hydrogen, carbon monoxide and liquefied petroleum gas given the turbulence of air generated by UAV propellers during its movement and optimize the complex these features. The scientists concluded that their system has the highest measurement accuracy only at UAV speeds up to $6 \mathrm{~m} / \mathrm{s}$, and at speeds above this value there is a significant decrease in the accuracy of the obtained data.

\subsection{Legal features of the use of UAVs in the system of operational monitoring of the atmosphere during emergencies in Ukraine}

As noted in the previous section, currently unmanned aerial vehicles have an unsurpassed impact on the speed and quality of research in various spheres of life: economy, industry, science, socio-cultural life.

The rapid development of the scope of UAVs has led to the rapid development of interception technologies for remote-controlled unmanned aerial vehicles. These technologies propagate a large number of signals in a certain frequency range, which prevents the exchange of information between the control station and the radio transmitter of the aircraft with a radius of several kilometers, but most modern unmanned aerial vehicles have protection against radio noise and interception. Radio interception can be hindered by the use of an autopilot module in the UAV, with a preset task of the desired flight route to the program of the aircraft, which in this case has a mediocre value of data exchange with the control station - can transmit real-time images and data not used during flight.

Anyhow, the use of UAVs for any purpose in Ukraine is clearly regulated by regulations, in particular: The Air Code of Ukraine [41]; Regulations on the use of airspace of Ukraine [42] and the Rules of use of airspace of Ukraine [43].

The State Aviation Service of Ukraine has published a map of zones [44] with restrictions on the flight of unmanned aerial vehicles. The UAV flight area has a specific character and is strictly regulated by such organizations as the State Agency of Civil Aviation and the Armed Forces of Ukraine. The result of regulation are areas where flights are prohibited in whole or in part limited by the size of the UAV or time of day. In accordance with the requirements of paragraph 4 of section II of the Rules of use of airspace [43], flights of unmanned aircraft weighing up to $20 \mathrm{~kg}$ inclusive are performed without submitting applications for use of airspace, without obtaining permits for use of airspace, without informing the Air Force of the Armed Forces of Ukraine and bodies of the joint civil-military system of air traffic organization of Ukraine, bodies of the State Border Guard Service of Ukraine, air traffic service bodies and departmental air traffic control bodies, subject to compliance with certain requirements space".

Though, emergencies may be defined by Ukrainian law as force majeure, or endangering the health and wellbeing of the population, and unmanned vehicles, which are registered on the balance of the State Emergency Service as means of performing special operations to search and eliminate emergencies, their consequences, as 
well as for the search for victims, as defined in the Air Code of Ukraine, section 4 "use of airspace of Ukraine", Article 24, paragraphs 1-5 [41].

\section{Discussion}

After analyzing the above studies, we conclude that the most promising area of environmental research is the use of modern remote, including multisensory, means of prevention and during emergencies in man-made areas and facilities.

Comprehensive development and implementation of new remote multisensory and multispectral means technical means of environmental control, taking into account the impact of their characteristics and parameters on the effectiveness of the process of controlling ground air pollution and assessing the ecological state of the atmosphere of technogenically loaded areas and objects has the aim of operational monitoring of the quality of the ground layer of atmospheric air, reduction of risks to health and life of specialists working in the emergency zone, or one that requires rapid surgical intervention for further localization and elimination.

Based on the analysis, we propose an improved scheme (Fig.4) of work of units of the State Emergency Service of Ukraine (SESU), which shows two algorithms for responding to an emergency - classic and recommended. In classical algorithm we distinguish five basic steps:

- the first stage is the time from the objective beginning of the emergency situation, to the moment when the fact of the emergency is noticed by people;

- the second - starts from the moment of detection of emergency and attempt of independent reconnaissance by non-experts (people nearby) to a call of crew of SESU;

- the third is the arrival of the rescue service team and reconnaissance of the scene by specialists, with or without special means;

- the fourth is creation of a staff of liquidation of emergency situations, development of the plan of liquidation, adjustment of structure of crew, etc.

- the fifth stage, which is directly to take action to eliminate this emergency.

The classical algorithm has two main disadvantages. The first is the response time, which increases significantly in areas where there are no people, or their number is insignificant (for example, land plots of warehouses, landfills, slag dumps, and other objects of man-made origin). The second significant disadvantage is the high risks to life and health of all people in contact with the emergency zone, especially if they do not have adequate personal protective equipment against any dangerous effects that occur in this area. These two shortcomings are interdependent, as due to the increased response time, the scale of the emergency increases, and therefore not only the natural area but also the people there are more negatively affected.

In contrast to the classical response scheme, the recommended scheme, provided it is properly implemented, is as free as possible from the shortcomings of the classical response scheme, and significantly simplifies and speeds up the work of units of the SES of Ukraine.

\section{Conclusions}

Emergencies will accompany humanity as long as society exists, and therefore it is very important to pay attention to the sustainable development of the response to emergencies, including environmental ones.

The article considers the features of the study of the surface layer of atmospheric air, reviews the existing remote means of monitoring the condition of this layer and also proposes a new functional scheme of response of the State Emergency Service of Ukraine to emergencies.

In order to talk about the monitoring of the surface layer of atmospheric air, it was necessary to determine the boundaries of this layer. Based on literary and logical theses, the authors of the article determined that the airspace at altitudes from $1.5 \mathrm{~m}$ to $500 \mathrm{~m}$ inclusive.

Based on the comparison of different remote means of environmental air quality monitoring, it can be stated that of all analyzed means, in particular - stationary automatic stations, mobile automatic stations, probes and unmanned aerial vehicles, it is proposed to use the latter as a remote means of operational air quality control. time of emergencies at the enterprise.

The proposed functional scheme of implementation of the UAV system for the needs of operational environmental monitoring of Ukraine will significantly reduce the response time to emergencies at enterprises, although it requires closer relationships "enterprise-unit of the SES of Ukraine" than those that exist now - mostly verifiable. The problem of implementing this functional scheme is the predominant distrust of entrepreneurs to regulatory authorities, which also indicates the need to restructure and reorganize the state emergency service of Ukraine to strengthen its basic functions to protect the population and property of Ukraine from natural and unnatural factors.

Analyzed legal features of the use of unmanned aerial vehicles as a remote means of air quality control during emergencies suggest that the use of UAVs as an additional means of monitoring air quality in the enterprise, as well as its sanitary protection zone is not only possible but also easily implemented. the existing regulatory framework of the state.

The use of modern means of remote monitoring of environmental quality, including unmanned aerial vehicles, will make the field of operational (crisis) monitoring of Ukraine more effective and timely, compared to the existing system of emergency response, which could potentially be responsible for environmental disasters in the region, region, country or even in a crossborder arena. In addition, such optimization will not only optimize the response time to emergencies, but will also be the first link in the whore to develop the scope of rapid response in the concept of sustainable development. 


\section{References}

1. J. Park, et al., Atmospheric Pollution Research, (2020). doi:10.1016/j.apr.2020.08.010

2. Y. Zhang, Z. Ding, Q. Xiang, W.Wang, L. Huang \& F. Mao, Short-term effects of ambient PM1 and PM2.5 air pollution on hospital admission for respiratory diseases: Case-crossover evidence from Shenzhen, China. Int. J. of Hyg. and Environmental Health, (2019). doi: 10.1016/j.ijheh.2019.11.001

3. S. Zangari, D. T. Hill, A. T. Charette \& J. E. Mirowsky, Air quality changes in New York City during the COVID-19 pandemic. Science of The Total Environment, $\mathbf{7 4 2}$ (2020). doi: 10.1016/j.scitotenv.2020.140496

4. M. Sarfraz, K. Shehzad \& S. G. Meran Shah, The impact of COVID-19 as a necessary evil on air pollution in India during the lockdown. Environmental Pollution, (2020). doi: 10.1016/j.envpol.2020.115080

5. A.Tobías, C. Carnerero, C. Reche, J. Massagué, M. Via, M. C. Minguillón, ... X. Querol, Changes in air quality during the lockdown in Barcelona (Spain) one month into the SARS-CoV-2 epidemic. Science of The Total Environment, (2020). doi: 10.1016/j.scitotenv.2020.138540

6. Kabinet Ministriv Ukrainy: Pro zatverdzhennya pereliku priorytetnykh tematychnykh napryamiv naukovykh doslidzhen' i naukovo-tekhnichnykh rozrobok na period do 2020 roku (About the statement of the list of priority thematic directions of scientific researches and scientific and technical developments for the period till 2020). https://zakon.rada.gov.ua/go/942-2011-\%D0\%BF

(2011). Accessed Nov 282020

7. Prezydent Ukrainy: Pro Tsili staloho rozvytku Ukrayiny na period do 2030 roku (On the Sustainable Development Goals of Ukraine until 2030). https://zakon.rada.gov.ua/laws/show/722/2019?lang =en (2019). Accessed 21 Nov 2020

8. Kabinet Ministriv Ukrainy: Pro skhvalennya Kontseptsiyi stvorennya zahal'noderzhavnoyi avtomatyzovanoyi systemy "Vidkryte dovkillya" (About the approval of the Concept of creation of the national automated system "Open environment"). https://zakon.rada.gov.ua/laws/show/825-2018\%D1\%80 (2018). Accessed 21 Nov 2020

9. Horizon Europe. https://ec.europa.eu/info/horizoneurope_en (2020). Accessed 21 Nov 2020

10. Derzhavnyy Standart Ukrayiny (DSTU): 3992-2000 Klimatolohiya. Terminy ta vyznachennya osnovnykh ponyat'(State Standard of Ukraine (DSTU): $3992-$ 2000 Climatology. Terms and definitions of basic concepts).http://online.budstandart.com/ua/catalog/d oc-page.html?id_doc $=69183$. (2000) Accessed Nov 282020

11. European Union: Directive 2008/50 / EC of the European Parliament and of the Council of 21 May 2008 on ambient air quality and cleaner air for Europe.

https://zakon.rada.gov.ua/laws/show/994_950\#n340 (2008). Accessed Nov 282020

12. O.H. Shevchenko, Vplyv inversiy na riven' zabrudnennya atmosfernoho povitrya mista Kyyeva (Influence of inversions on the level of air pollution in Kyiv). Ukr. Hidro-met. J., 8 (2011).

13. M. Berland, Modern problems of atmospher-ic diffusion and air pollution» (Sovremennyye problemy atmosfernoy diffuzii i zagryazneniya atmosfery), Gidrometeoizdat, 448 (1975).

14. O. Popov, A. Iatsyshyn, V. Kovach, V. Artemchuk, D. Taraduda, V. Sobyna, D. Sokolov, M. Dement, V.Hurkovskyi, K. Nikolaiev, T. Iatsyshyn, D. Dimitriieva, Physical Features of Pollutants Spread in the Air During the Emergency at NPPs. Nucl. and Rad. Saf., 4(84), 88-98 (2019). doi: 10.32918/nrs.2019.4(84).11

15. N.N. Belyaev, T.I. Rusakova, V.E. Kolesnik, A.V. Pavlichenko, Forecast of the level of atmospheric air pollution in the zone of influence of urban highways. Scient. Bull. of the Nat. Min. Univ., 1, 90 - 97 (2016).

16. M. Radomska, S. Madzhd, L. Cherniak, O. Mikhyeyev Environmental pollution in the airport impact area-case study of the Boryspil. Env. Probl., 5 (2), 76-82 (2020).

17.S. M. Kvaternyuk, Analiz strukturnykh skhem zasobiv mul'tyspektral'noho televiziynoho vymiryuval'noho kontrolyu parametriv ta diahnostuvannya stanu neodnoridnykh biolohichnykh (Analysis of structural diagrams of multispectral television measuring control parameters and diagnosing the state of inhomogeneous biological media) Opt. elect. inf. energ. techn. J., 1, 54-60 (2017). http://nbuv.gov.ua/UJRN/oeiet_2017_1_10 Accessed Nov 282020

18. N. Hagen \& M. W. Kudenov, Review of snapshot spectral imaging technologies. Optic. Engin., 52 (9), (2013). doi: 10.1117/1.oe.52.9.090901

19. Andrii Iatsyshyn, Anna Iatsyshyn, V. Kovach, I. Zinovieva, V. Artemchuk, O. Popov, O. Cholyshkina, Oleksandr Radchenko, Oksana Radchenko, A. Turevych, Application of Open and Specialized Geoinformation Systems for Computer Modelling Studying by Students and PhD Students. CEUR Workshop Proceedings 2732, 893-908. http://ceurws.org/Vol-2732/20200893.pdf (2020). 
20. Kirchner, M., Freier, K. P., Denner, M., Ratz, G., Jakobi, G., Körner, W., ... Moche, W. Air concentrations and deposition of chlorinated dioxins and furans (PCDD/F) at three high alpine monitoring stations: Trends and dependence on air masses. Atmospheric

Environment, (2019). doi:10.1016/j.atmosenv.2019.117199

21. Ma, J., Li, Z., Cheng, J. C. P., Ding, Y., Lin, C., \& $\mathrm{Xu}, \mathrm{Z}$. (2019). Air quality prediction at new stations using spatially transferred bi-directional long shortterm memory network. Science of The Total Environment,

135771. doi:10.1016/j.scitotenv.2019.135771

22. I. Hůnová, V. Bäumelt and M. Modlík, Long-term trends in nitrogen oxides at different types of monitoring stations in the Czech Republic, Science of the Total Environment (2019), https://doi.org/10.1016/j.scitotenv.2019.134378

23. Alterio, E., Cocozza, C., Chirici, G., Rizzi, A., \& Sitzia, T. (2020). Preserving air pollution forest archives accessible through dendrochemistry. Journal of Environmental Management, 264, (2020). doi:10.1016/j.jenvman.2020.110462

24. Arfire A. Marjovi A., Martinoli A.Enhancing Measurement Quality Through Active Sampling In Mobile Air Quality Monitoring Sensor Networks. Proceedings of the IEEE International Conference on Advanced Intelligent Mechatronics (Banff, Alberta, Canada, July 12-15, 2016), 313-321,(2016). https://doi.org/10.1109/AIM.2016.7576904

25. Castell N., Kobernus M., Liu H.-Y., Schneider P., Lahoz W., Berre A.J., Noll J. Mobile technologies and services for environmental monitoring: The CitiSense-MOB approach. Urban Climate, 14(3), 370 382 https://doi.org/10.1016/j.uclim.2014.08.002

(2015).

26. i3 Kang L. Poslad S., Wang W., Li X., Zhang Y., Wang C. A Public Transport Bus as a Flexible Mobile Smart Environment Sensing Platform for IoT. Proceedings of the 2016 12th International Conference on Intelligent Environments (London, UK, September 14-16, 2016). 1-8 (2016). https://doi.org/10.1109/IE.2016.10

27. Lancia G. Rinaldi F., Serafini P. A Facility Location Model for Air Pollution Detection. Mathematical Problems in Engineering. 1-8 (2018). https://doi.org/10.1155/2018/1683249

28. Liu L. Duan J., Xiao Z., Wang C., Li X. A FaultTolerant Mobile Sensing Information Gathering Center (MSIGC) Using Public Transport Buses to Instrument a Smart City. Proceedings of the 2017 9th International Conference on Advanced Infocomm Technology. 233-238 (2017). https://doi.org/10.1109/ICAIT.2017.8388921

29. Raju H.P., Partheeban P., Hemamalini R.R. Urban Mobile Air Quality Monitoring Using GIS, GPS,
Sensors and Internet. Int. J. of Env. Sc, \& Dev., 3 (4), 323-327 (2012). doi: 10.7763/IJESD.2012.V3.240

30. Y. Huang, W. Mok, Y. Yam, J. L. Zhou, N. C. Surawski, B. Organ, ... H. C. Ong, Evaluating in-use vehicle emissions using air quality monitoring stations and on-road remote sensing systems. J. Sc. of The Tot. Env., (2020). doi:10.1016/j.scitotenv.2020.139868

31. E.G. Tolstykh, Improvement of models and methods of radioacoustic sounding of the atmosphere. Dissertation. National University of Radio Electronics (Kharkiv), 2018.

32. C.L. Wood, S.H. Sokolow, I.J. Jones, A.J. Chamberl in, K.D. Lafferty, at al., Precision mapping of snail habitat provides a powerful indicator of human schistosomiasis transmission/ / Proc. of the Nat. Ac. of Sc., $116(46)$, (2019). doi: 10.1073/pnas. 1903698116

33. K. Smetanin, Osoblyvosti vykorystannya bezpilotnykh lital'nykh aparativ $\mathrm{v}$ ekolohichnomu monitorynhu. Systemy upravlinnya, navihatsiyi ta zv"yazku (Features of the use of unmanned aerial vehicles in environmental monitoring). Contr., navig, and com. syst. J., 3 (49), 22-25 (2018). doi: 10.26906/SUNZ.2018.3.022

34. V. O. Sekret, Vykorystannya kompleksiv BPLA pidrozdilamy DSNS. Nauka pro cevyl’nyj zaxyst yak shlyax stannovlennya molodyx vchenyx (Use of UAV complexes by SES units. The science of evil protection as a way of becoming young scientists). 119 (2019).

35. B.Moroz, A. Antipov \& V. Zhuravlev Avtomatyzovana systema dostavky medykamentiv za dopomohoyu bezpilotnyx lital"nyx aparativ (mul"tykopteriv) za zapytom spozhyvacha(Automated system of drug delivery by means of unmanned aerial vehicles (silt polycopters) at the request of the consumer). J. comp.-integr. techn.: educ., sc., prod., 35, 47-54 (2019).

36. V. Hlotov, A. Hunina \& Yu. Teleshhuk, Analiz mozhlyvostej zastosuvannya bezpilotnyx lital"nyx aparativ dlya vijs"kovyx cilej(Analysis of the possibilities of using unmanned aerial vehicles for axle casing purposes). Suchasni dosyahnennya heodezychnoyi nauky ta vyrobnyctva, 1, 139-146 (2017).

37. M. A. Mykytyuk, Rol' ta misce bezpilotnyx lital’nyx aparativ pry zabezpechenni bezpeky osib pid chas provedennya masovyx zaxodiv(The role and place of unmanned aerial vehicles in ensuring the safety of persons during mass events). Scientific Notes of Lviv University of Business and Law ,18, $41-47$ (2017).

38. A. O. Zaporozhets, Analysis of means for monitoring air pollution in the environmental. Naukoyemni 
tekhnolohiyi, 3 (35) (2017). doi: 10.18372/23105461.35 .11844

39. J. Burgués \& S. Marco, Environmental chemical sensing using small drones: A review. Science of The Total Environment. (2020). doi: 10.1016/j.scitotenv.2020.141172

40. R. Noori, D.P. Dahnil, The effects of speed and altitude on wireless air pollution measurements using hexacopter drone. Int. J. of Adv. Comp. Sci. and Appns, 11 (2020)

41. Povitryanyj kodeks Ukrayiny: Kodeks Ukrayiny (Air Code of Ukraine: Code of Ukraine), https://zakon.rada.gov.ua/go/3393-17 (2011). Accessed Nov 282020

42. Kabinet Ministriv Ukrainy: Pro zatverdzhennya Polozhennya pro vykorystannya povitryanoho prostoru Ukrayiny (On approval of the Regulations on the use of airspace of Ukraine) https://zakon.rada.gov.ua/go/954-2017-\%D0\%BF (2017) Accessed Nov 282020

43. Derzhaviasluzhba Ukrayiny: Pro zatverdzhennya Aviatsiynykh pravyl Ukrayiny «Pravyla vykorystannya povitryanoho prostoru Ukrayiny» (State Aviation Service of Ukraine: On approval of the Aviation Rules of Ukraine "Rules for the use of airspace

of Ukraine").URL:https://zakon.rada.gov.ua/go/z105618 (2018).Accessed Nov 282020

44. Derzhavna aviacijna sluzhba Ukrayiny: Zony zaboron ta obmezhen" vykorystannya povitryanoho prostoru. https://avia.gov.ua/bezpilotni-povitryanisudna-2/zoni-zaboron-ta-obmezhen-vikoristannyapovitryanogo-prostoru/(2018). Accessed 28 Nov 2020

45. Virazh aero photogallery http://uav.nau.edu.ua/fotom10.html Accessed Dec 05 2020

46. Ambient Air Monitoring Network Review. https://content.govdelivery.com/accounts/MIDEQ/b ulletins/1f1e994 Accessed Dec 052020

47. Environment: Air Pollution and Public Fleet Management. https://www.energyiot.co.th/applications Accessed Dec 052020

48. DJI Matrice M600. www.dji.com/matrice600 Accessed Dec 052020

49. O. Popov, A. Iatsyshyn, V. Kovach, V. Artemchuk, I. Kameneva, D. Taraduda, V. Sobyna, D. Sokolov, M. Dement, T. Iatsyshyn, Risk assessment for the population of Kyiv, Ukraine as a result of atmospheric air pollution. J. Health Pollut. 10, 200303 (2020). doi:10.5696/2156-9614-10.25.200303

50. A. Iatsyshyn, A. Iatsyshyn, V. Artemchuk, I. Kameneva, V. Kovach, O. Popov, Software tools for tasks of sustainable development of environmental problems: peculiarities of programming and implementation in the specialists' preparation. E3S Web Conf. 166, 01001 (2020). doi:10.1051/e3sconf/202016601001

51. A.O. Zaporozhets, V.V. Khaidurov, Mathematical Models of Inverse Problems for Finding the Main Characteristics of Air Pollution Sources. Water Air Soil Pollut. 231, 563 (2020). doi:10.1007/s11270020-04933-z

52. V. Zaporozhets, V. Babak, at al. Analysis of the Air Pollution Monitoring System in Ukraine, in Studies in Systems, Decision and Control Systems, 298, 85-110 ed. by V. Babak, V. Isaienko, A. Zaporozhets (Springer, Cham, 2020). doi:10.1007/978-3-03048583-2 6

53. A. Zaporozhets, Overview of Quadrocopters for Energy and Ecological Monitoring, in Studies in Systems, Decision and Control Systems, 298, 15-36, ed. by V. Babak, V. Isaienko, A. Zaporozhets (Springer, Cham, 2020). doi:10.1007/978-3-03048583-2_2 